\title{
Fibrinolysis and the bleeding tendency in patients with hepatosplenic schistosomiasis
}

\author{
S A Omran, N A Hussein, A A Mohamed, A H El-Kaliouby, A T Hussein
}

\begin{abstract}
Fifty seven patients with schistosomiasis of the liver and spleen in both the compensated and decompensated states and 15 non-bilharzial subjects were studied. Fibrinogen, plasminogen, fibrinogen/ fibrin degradation products, $\alpha_{2}$ macroglobulin, antithrombin III and $\mathrm{Cl}$ activator concentrations were evaluated in an attempt to assess abnormalities at various stages of the disease. The results showed a progressive decrease in fibrinogen and plasminogen concentrations; fibrin degradation products showed a progressive increase as the disease progressed. Together with a falling platelet count, these data indicate the possible occurrence of disseminated intravascular coagulation with enhanced fibrinolysis which was most pronounced in those who vomited blood. Antithrombin III concentration showed a progressive decrease in parallel with the progress of the disease, possibly due to decreased synthesis or increased consumption, or both. Clactivator concentration showed no significant change from that in normal controls at any stage of the disease. These findings provide further evidence that disseminated intravascular coagulation and enhanced fibrinolysis in the late stages of schistosomiasis may contribute to the haemorrhagic diathesis seen in the liver and spleen.
\end{abstract}

A major health problem in various parts of the world and in Egypt is schistosomiasis of the liver and spleen. ${ }^{1}$ The disease is well known for the bleeding tendency that may result from diminished synthesis of coagulation factors, fibrinolytic system activation, and consumption coagulopathy..$^{2-4}$ Acute attacks of haematemesis from ruptured oesophageal varices are often life-threatening and are probably exacerbated by impaired haemostatic and fibrinolytic mechanisms. ${ }^{5}$

We studied some variables of the fibrinolytic system, both in compensated and decompensated states of the disease, to clarify the part played by fibrinolytic activity during the acute attacks of haematemesis secondary to ruptured oesophageal varices.

\section{Methods}

This study included 72 subjects: 15 normal controls, and 57 patients with schistosomiasis in whom disease was confirmed by urine and stool analysis, sigmoidoscopic examination, rectal biopsy, ultrasonography and by liver biopsy whenever possible. Patients were further classified into compensated and decompensated groups: the former were subdivided into 15 patients with enlarged liver and spleen (group 1) and 15 with an enlarged spleen only (group 2); and the latter comprised patients with advanced hepatic fibrosis with ascites (15 cases, group 3) and 12 patients who had acute attacks of haematemesis from ruptured oesophageal varices (group 4). Blood differential, platelet count, prothrombin time and liver function tests were carried out and antibodies to hepatitis B surface antigen ( $\mathrm{HBs} A g$ ) were measured in all members of the study. The patients included in groups $1-4$ were negative for HBsAg. Plasma fibrinogen concentration was determined by a modified Clauss method, ${ }^{6}$ using the Multifibren test kit (Behring Institute, Mannheim, West Germany). Plasminogen concentration was estimated by $\mathrm{M}$ Partigen immunodiffusion plates (Behring Institute). The quantitative determination of $\alpha_{2}-$ macroglobulin, $\mathrm{Cl}$-activator, and antithrombin III was done with Nor-Partigen immunodiffusion plates (Behring Institute). Estimation of fibrin degradation products was done with staphylococcal clumping test ${ }^{7}$ using a Fibro Tec Combipack Kit (Behring Institute).

\section{Results}

The results obtained from this study showed a progressive decrease in platelet count and fibrinogen, plasminogen and antithrombin III concentrations as the disease progressed, while fibrin degradation products progressively increased. The $\alpha_{2}$-macroglobulin concentration was raised in group 1 patients, group 2 patients, and in those with ascites (group 3), and was normal in group 4 patients. $\mathrm{Cl}$-inactivator was within the conventional range of normal in all of the groups (table).

Statistical analysis (Mann-Whitney U test) ${ }^{8}$ showed a significant difference between the control group and the group 1 in fibrinogen degradation products and $\alpha_{2}$-macroglobulin concentration ( $p<0.001$ ) and a significant difference in fibrinogen, plasminogen, and antithrombin III concentrations $(p<0.01)$. The difference between the control group and the other diseased groups was significant for all the aforementioned variables $(p<0.001)$, except for $\alpha_{2}$-macroglobulin during acute attacks of haematemesis $(p>0.05)$. The difference between group 1 and group 2 was significant for antithrombin III ( $p<0.001$ ), significant for plasminogen $(p<0.01$ ), but 
Tested variables in normal controls and disease groups

\begin{tabular}{|c|c|c|c|c|c|c|c|c|c|}
\hline & & $\begin{array}{l}\text { Fibrinogen } \\
(m g / d l)\end{array}$ & $\begin{array}{l}\text { Plasminogen } \\
(m g / d l)\end{array}$ & $\begin{array}{l}\text { Fibrin } \\
\text { degradation } \\
\text { products } \\
(\mu g / m l)\end{array}$ & $\begin{array}{l}\alpha_{2} \text {-macro- } \\
\text { globulin } \\
(\mathrm{g} / \mathrm{l})\end{array}$ & $\begin{array}{l}\text { Anti- } \\
\text { thrombin III } \\
(\mathrm{g} / \mathrm{l})\end{array}$ & $\begin{array}{l}\text { Cl-inactivator } \\
(\boldsymbol{g} \mid \boldsymbol{l})\end{array}$ & $\begin{array}{l}\text { Platelets } \\
\left(10^{3} / l\right)\end{array}$ & $\begin{array}{l}\text { Prothrombin } \\
\text { time } \\
\text { (seconds) }\end{array}$ \\
\hline $\begin{array}{l}\text { Normal } \\
\text { controls } \\
(n=15)\end{array}$ & $\begin{array}{l}\text { Range } \\
\text { Median } \\
\text { Mean (SD) }\end{array}$ & $\begin{array}{l}253-412 \\
331 \\
333 \cdot 47(48 \cdot 37)\end{array}$ & $\begin{array}{l}10.6-20.0 \\
11.8 \\
12.53(2.46)\end{array}$ & $\begin{array}{l}2 \cdot 88-5 \cdot 76 \\
5 \cdot 76 \\
4 \cdot 61(1 \cdot 46)\end{array}$ & $\begin{array}{l}1.86-2.9 \\
2.63 \\
2.6(0.32)\end{array}$ & $\begin{array}{l}0.272-0.375 \\
0.300 \\
0.315(0.035)\end{array}$ & $\begin{array}{l}0.240-0.288 \\
0.252 \\
0.253(0.015)\end{array}$ & $\begin{array}{l}200-350 \\
280 \\
278(44 \cdot 51)\end{array}$ & $\begin{array}{l}11-12 \cdot 7 \\
11.9 \\
11.89(0.45)\end{array}$ \\
\hline \multicolumn{10}{|c|}{ Compensated form: } \\
\hline $\begin{array}{l}\text { Group 1 } \\
\quad(n=15) \\
\text { Group 2 } \\
\quad(n=15)\end{array}$ & $\begin{array}{l}\text { Range } \\
\text { Median } \\
\text { Mean (SD) } \\
\text { Range } \\
\text { Median } \\
\text { Mean (SD) }\end{array}$ & $\begin{array}{l}196-358 \\
253 \\
266 \cdot 7(53 \cdot 16) \\
180-307 \\
227 \\
233 \cdot 53(36 \cdot 94)\end{array}$ & $\begin{array}{l}6 \cdot 0-12 \cdot 6 \\
10 \cdot 6 \\
9 \cdot 64(2 \cdot 31) \\
3 \cdot 0-10 \cdot 6 \\
7 \cdot 4 \\
7 \cdot 12(2 \cdot 69)\end{array}$ & $\begin{array}{l}5 \cdot 76-46.08 \\
23.04 \\
23.42(13.15) \\
23.04-46.08 \\
23.04 \\
30 \cdot 72(11 \cdot 2)\end{array}$ & $\begin{array}{l}2.9-6 \cdot 15 \\
3.93 \\
4.06(1.05) \\
2.36-5 \cdot 78 \\
3.78 \\
3.78(0.98)\end{array}$ & $\begin{array}{l}0.168-0.344 \\
0.231 \\
0.242(0.05) \\
0.111-0.218 \\
0.168 \\
0.174(0.029)\end{array}$ & $\begin{array}{l}0.154-0.449 \\
0.217 \\
0.253(0.094) \\
0.154-0.313 \\
0.262 \\
0.24(0.055)\end{array}$ & $\begin{array}{l}21-380 \\
140 \\
146 \cdot 13(97 \cdot 97) \\
26-166 \\
55 \\
78 \cdot 06(41 \cdot 19)\end{array}$ & $\begin{array}{l}12-14.9 \\
13.3 \\
13.1(0.93) \\
11 \cdot 4-17.9 \\
14.5 \\
14.82(1.87)\end{array}$ \\
\hline \multicolumn{10}{|c|}{ Decompensated form: } \\
\hline $\begin{array}{c}\text { Group 3 } \\
(n=15) \\
\text { Group 4 } \\
(n=12)\end{array}$ & $\begin{array}{l}\text { Range } \\
\text { Median } \\
\text { Mean (SD) } \\
\text { Range } \\
\text { Median } \\
\text { Mean (SD) }\end{array}$ & $\begin{array}{l}139-269 \\
196 \\
197 \cdot 07(36 \cdot 61) \\
83-259 \\
151 \cdot 5 \\
164 \cdot 33(61 \cdot 3)\end{array}$ & $\begin{array}{l}3 \cdot 0-10 \cdot 6 \\
5 \cdot 2 \\
5 \cdot 71(2 \cdot 26) \\
3 \cdot 0-4 \cdot 6 \\
3 \cdot 6 \\
3 \cdot 5(0 \cdot 52)\end{array}$ & $\begin{array}{l}46 \cdot 08-92 \cdot 16 \\
46 \cdot 08 \\
64 \cdot 51(23 \cdot 37) \\
92 \cdot 16-368 \cdot 6 \\
184 \cdot 32 \\
215 \cdot 0(120 \cdot 0)\end{array}$ & $\begin{array}{l}2.63-6.52 \\
3.48 \\
3.76(1.08) \\
1.29-3.18 \\
2.62 \\
2.47(0.68)\end{array}$ & $\begin{array}{l}0.06-0.168 \\
0.144 \\
0.129(0.039) \\
0.06-0.144 \\
0.116 \\
0.11(0.03)\end{array}$ & $\begin{array}{l}0.134-0.352 \\
0.240 \\
0.242(0.063) \\
0.125-0.288 \\
0.240 \\
0.227(0.05)\end{array}$ & $\begin{array}{l}38-90 \\
71 \\
69 \cdot 82(15 \cdot 2) \\
30-90 \\
51 \cdot 5 \\
56 \cdot 25(17 \cdot 75)\end{array}$ & $\begin{array}{l}13.5-20.4 \\
15.8 \\
15.89(1.74) \\
15.8-25 \\
17.9 \\
18.63(2.66)\end{array}$ \\
\hline
\end{tabular}

not for fibrinogen, fibrinogen degradation products, and $\alpha_{2}$-macroglobulin ( $p>0.05$ ). The difference between group 1 and the groups 3 and 4 was significant for plasminogen, fibrinogen degradation products, antithrombin III $(p<0.001)$ and fibrinogen $(p<0.01)$, and that for $\alpha_{2}$-macroglobulin was significant for group 4 ( $p<0.01)$, but not for group 3 (p > $0.05)$. The difference between group 2 and group 3 patients was significant for fibrin degradation products $(p<0.001)$, fibrinogen, and antithrombin III ( $p<0.01$ ), but not for plasminogen and $\alpha_{2}$-macroglobulin ( $p>0.05$ ). As regards groups 2 and 4, the difference was significant for plasminogen, antithrombin III, and fibrin degradation products $(p<0.001)$, as well as for fibrin and $\alpha_{2}$-macroglobulin ( $p<$ 0.01 ). Groups 3 and 4 patients showed a significant difference in concentrations of fibrin degradation products ( $p<0.001$ ), plasminogen, and $\alpha_{2}$-macroglobulin $(\mathrm{p}<0.01)$ but not in fibrinogen or antithrombin III $(p>$ 0.05). Cl-inactivator was the same for all groups tested.

\section{Discussion}

This study attempted to shed light on the part played by fibrinolytic mechanisms in causing the haemostatic abnormalities seen in hepatosplenic schistosomiasis. The results obtained showed a progressive decrease in fibrinogen concentration as disease advanced which was more obvious in groups 3 and 4 . More than one factor is responsible for the hypofibrinogenaemia occurring in chronic liver disease: decreased hepatic synthesis; increased consumption during intravascular coagulation; destruction by abnormal plasma fibrinolytic activity; and unreplaced loss during massive haemorrhage from oesophageal varices. Exchange of plasma fibrinogen into ascitic fluid or increased catabolism will also hasten the rapid disappearance of fibrinogen from plasma. ${ }^{10}$ The progressive decrease in plasminogen concentration as disease advanced could be explained by decreased synthesis owing to hepatic fibrosis or increased consumption by enhanced fibrinolytic activity, or both. Fibrin degradation products were increased in patients' sera, being the lowest in group 1 and the highest in group 4 . The existence of the progressively increasing concentrations of fibrin degradation products on the one hand, and the progressive decrease of fibrinogen and plasminogen concentrations and platelet count on the other, could be accounted for by the enhanced fibrinolytic activity or disseminated intravascular coagulation, or both, which often accompany hepatic fibrosis in patients with schistosomiasis, especially in the advanced ascitic and haemorrhagic groups. The occurrence of disseminated intravascular coagulation could be attributable to exposure of blood to the expanded collaterals and the distorted splenic circulation in conjunction with impaired hepatic clearing of the procoagulants. " Localised intravascular coagulation might also be the outcome of microthrombi present in hepatic venules at the site of schistosomal granulomas, or pressure necrosis affecting the peripheral hepatocytes. ${ }^{12}$ The $\alpha_{2}$ macroglobulin concentration was increased in groups 1-3, reverting to normal in group 4, which differs from that of other acute phase proteins such as haptoglobin, transferrin, or $\alpha_{1}$ antitrypsin. These are known to decrease in chronic liver disease due to diminished synthesis by the liver-their main site of synthesis. The significant increase in $\alpha_{2}$-macroglobulin can thus be attributed to immunomodulatory functions, ${ }^{13}$ while its decrease in group 4 might be due to increased consumption in the complexes formed with excess plasmin and thrombin. ${ }^{14}$ Antithrombin III concentration progressively decreased as the disease advanced, probably as a result of impaired hepatic synthesis and increased consumption. ${ }^{15} \mathrm{Cl}-$ inactivator concentration showed no significant difference between the disease groups and normal controls in any stage of the disease.

The data obtained from group 4 during acute attack of haematemesis showed low concentrations of fibrinogen, plasminogen, and $\alpha_{2}$ macroglobulin, a low platelet count and very high concentration of fibrin degradation products. These data indicate that increased fibrinolysis or disseminated intravascular coagulation, or both, may be present during an acute attack of haematemesis. This suggests 
that disseminated intravascular coagulation and increased fibrinolysis are important factors that underlie the haemorrhagic diathesis seen in hepatosplenic schistosomiasis.

1 Abdel-Wahab M. Schistosomiasis in Egypt. CRC Press Inc, 1988

2 Omran S, El-Ashmawy S. Coagulation studies in bleeding cases of hepatosplenic schistosomiasis. Egypt J Haematol 1979;4:223-34.

3 Omran S, Toima SM, Shams El-Din A. In vitro study on the effect of schistosoma worm antigen on blood coagulation. Egyptian Journal of Bilharziasis 1988;10:165-73.

4 Madkour M, El-Ashmawy S, El-Razky S, Omran S. Study of fibrinolytic activity in different stages of hepatosplenic of fibrinolytic activity in different stages of hepatosplenic
schistosomiasis. [Thesis]. Cairo University, 1985:165-7. 5 Hussein A, Omran S, El-Bassioni N, El-Bihary N, Ragab G. Preliminary study of the coagulation mechanism in variceal bleeding. J Military Med Acad 1987;1:51-5.

6 Clauss A. Rapid physiological coagulation method in determination of fibrinogen. Acta Haematol (Basel) 1957 $17: 237-40$
7 Hawiger J, Niewiarowski S, Thomas D. Measurement of fibrinogen and fibrin degradation products in serum by 75:93-108.

8 Hamburg M, ed. Statistical analysis for decision making. 2nd ed. Chicago: Harcourt Brace Iovanovich, 1977:519-43.

9 Schiff L, Schiff E. Disordered haemostasis in hepatic disease. In: Diseases of the liver. 5 th ed. Philadelphia: J B disease. In: Diseases of the

10 Ruegg R, Straub P. Exchange between intravascularly and extravascularly injected radioiodinated fibrinogen and its in vivo derivatives. $J \mathrm{Lab}$ Clin Med 1980;95:842-8.

11 Verstraete $M$, Verymylen J, Collen D. Intravascular coagulation in liver disease. Ann Rev Med 1974;25: 447-52.

12 Abdel-Hady A, Abdeen F, El-Garem A, Badrawi N. A histopathological and immunohistochemical study of collagen in schistosomal hepatic fibrosis before and after chemotherapy. [Thesis]. Cairo University, 1987:303-7.

13 Meliconi R, Parracino O, Facchini A, Miglio F. Acute phase proteins in chronic and malignant liver disease. Liver

14 Jandle J, ed. Haemostasis. In: Textbook of haematology. Vo III. Boston: Little, Brown, \& Co, 1987:998-1005.

15 Thaler E, Lechner $\mathrm{K}$. Antithrombin III deficiency and thromboembolism. Clin Haematol 1981;10:369-90. 